\title{
Prevalence of Anxiety and Depression among Medical Students
}

\author{
Prevalência de Ansiedade e Depressão \\ entre Estudantes de Medicina
}

\author{
Fábio de Oliveira Tabalipa ${ }^{I}$ \\ Mariana Fuganti de Souza ${ }^{I}$ \\ Gláucia Pfützenreuter ${ }^{I}$ \\ Vinícius Carriero Limal \\ Eliane Traebert ${ }^{l}$ \\ Jefferson Traebert ${ }^{I}$
}

PALAVRAS-CHAVE

- Ansiedade;

- Depressão;

- Prevalência;

- Estudantes;

- Medicina;

- Educação Médica.

\section{KEYWORDS}

- Epidemiology;

- Anxiety;

- Depression;

- Prevalence;

- Students;

- Medical Education.
Recebido em: 23/10/2014

Aprovado em: 18/04/2015

\section{RESUMO}

Introdução: Estudantes de Medicina são uma população propícia ao desenvolvimento de transtornos de depressão e ansiedade. Objetivo: Estimar a prevalência de ansiedade e depressão entre acadêmicos de Medicina. Métodos: Estudo transversal envolvendo uma amostra aleatória e representativa $(n=$ 346) de estudantes de Medicina de uma universidade no Brasil. Os níveis de ansiedade e depressão foram aferidos pelos Inventários de Depressão e Ansiedade de Beck. Análises brutas e ajustadas foram realizadas utilizando-se regressão de Poisson. Resultados: A prevalência de ansiedade foi de 35,5\%, e a de depressão, 32,8\%. Mulheres apresentaram prevalência 14\% maior de ansiedade e 16\% maior de depressão ( $p=0,025$ e $p=0,006$, respectivamente). Estudantes com pais não médicos apresentaram prevalência de ansiedade $23 \%$ maior $(p=0,006)$, e aqueles com pais médicos, prevalência de depressão 29\% maior ( $p=0,034$ ). Aqueles que se sentiam sempre ou frequentemente cobrados pelos pais apresentaram ansiedade $22 \%$ maior $(p=0,006)$ e depressão $19 \%$ maior $(p=0,016)$. Estudantes que tinham preocupações com o futuro mostraram prevalência de depressão $15 \%$ maior $(p=0,017)$. Conclusões: A prevalência de sintomas depressivos e ansiosos foi superior à média encontrada na população em geral. 


\section{INTRODUCTION}

Difficulties encountered by medical students may affect their mental health. Constant exposure to stressful situations, such as pressure from parents, fear of failure and the labor market challenges are factors associated with increasing susceptibility to different kinds of emotional outbreaks ${ }^{1}$. It is estimated that $15 \%$ to $25 \%$ of medical students show some kind of psychiatric distress during their education, especially during medical training ${ }^{2}$.

Medical school is traditionally recognized as one of the most laborious, often by becoming a hostile environment of requirements which have ultimately a negative impact on the student's academic performance, physical health and psychosocial well-being ${ }^{3,4}$. There is great difficulty in adapting to the environment of medical schools, due to the distance from family and friends, student workload and amount of content to be studied, intimidation from the faculty, exposure to death and human suffering, and even to financial difficulties ${ }^{5}$. These variables contribute to the relatively high numbers of psychiatric disorder cases, especially depression and anxiety, among medical students ${ }^{2}$.

Depression and anxiety affect students both professionally and personally. Personal consequences include termination of relationships, substance abuse, health deterioration and decline in physical vigor. Professional consequences include academic performance decay, decline in empathy and ethics, academic dishonesty, negative influence on their choice of specialty and high incidence of medical errors ${ }^{6}$.

Medical students are at high risk of developing depression and anxiety disorders, which can reach levels of severity sufficient enough to bring important consequences to emotional, mental and physical well-being. Few management strategies are focused on these issues, primarily due to lack of knowledge of the main factors associated with these morbidities, and how to resolve them. The aim of this study was to estimate the prevalence, severity and associated factors of anxiety and depression disorders among medical students.

\section{METHODS}

\section{Study design and population}

This is a cross-sectional study involving medical students at a university in the Brazilian Southern State of Santa Catarina.

A representative sample of students enrolled in all semesters of medical school at both north and south campuses of the university was obtained. The parameters for calculating the sample were: confidence level of $95 \%$ ( $\square=5 \%$ ), relative error of $5 \%$ and unknown prevalence of the studied phenomena ( $P$ $=50 \%$ ) which generates the largest variance. The result was 248 participants. Considering possible losses or refusals and potential confounding factors of $20 \%$, the final sample included 346 subjects. The simple random sampling method was used to select the sample for the study. Individuals who refused to participate were considered to be losses.

\section{Data}

The data collection instrument included questions on sociodemographic features such as gender, age and parental education. Also, level of parental pressure and if parents were physicians; aspects related to the medical school, such as the semester in which they studied at the time of the survey and in which campus were included. Levels of anxiety and depression, using the Beck Depression Inventory (BDI) ${ }^{7}$ and the Beck Anxiety Inventory (BAI $)^{8}$ were assessed under the supervision of a trained psychologist.

The following cut-off points for depression were used, as recommended by the Center for Cognitive Therapy ${ }^{7}$ : less than $10=$ minor or no depression; $10-18=$ mild to moderate depression; $19-29$ = moderate to severe depression; and 30-63 = severe depression. As for anxiety, the recommendations of the manual were followed ${ }^{8}$ : less than or equal to $10=$ no anxiety symptoms; 11-19 = mild to moderate anxiety; 20-30 = moderate anxiety; and 31-63 points = clinically significant anxiety.

\section{Statistical analysis}

Poisson regression was used to estimate prevalence ratios (PR) and confidence intervals (95\%) in bivariate and multiple analyses, and to examine the association between anxiety, depression and the included variables. Variables with $p<.20$ in bivariate analysis were included in multivariate analysis, remaining in the final model if $\mathrm{p}<.05$.

\section{Ethical approval}

The study was submitted to and approved by the Ethics Committee on Human Research at the University of Southern Santa Catarina under protocol number 09.482.4.01.III. Only the medical students who signed the consent form participated in the study.

\section{RESULTS}

In total, 262 students participated in the study, 131 from each of the two campuses, representing an overall response rate of $75.5 \%$.

The questionnaire was completed by 147 women (56.1\%) and 115 men (43.9\%). The mean age of participants was 23.0 years $(\mathrm{SD}=3.3)$. Most of the surveyed subjects were single (91.6\%), whereas $7.3 \%$ were married and $1.1 \%$ were divorced. Few had children $(4.2 \%)$, and $24 \%$ had at least one parent with 


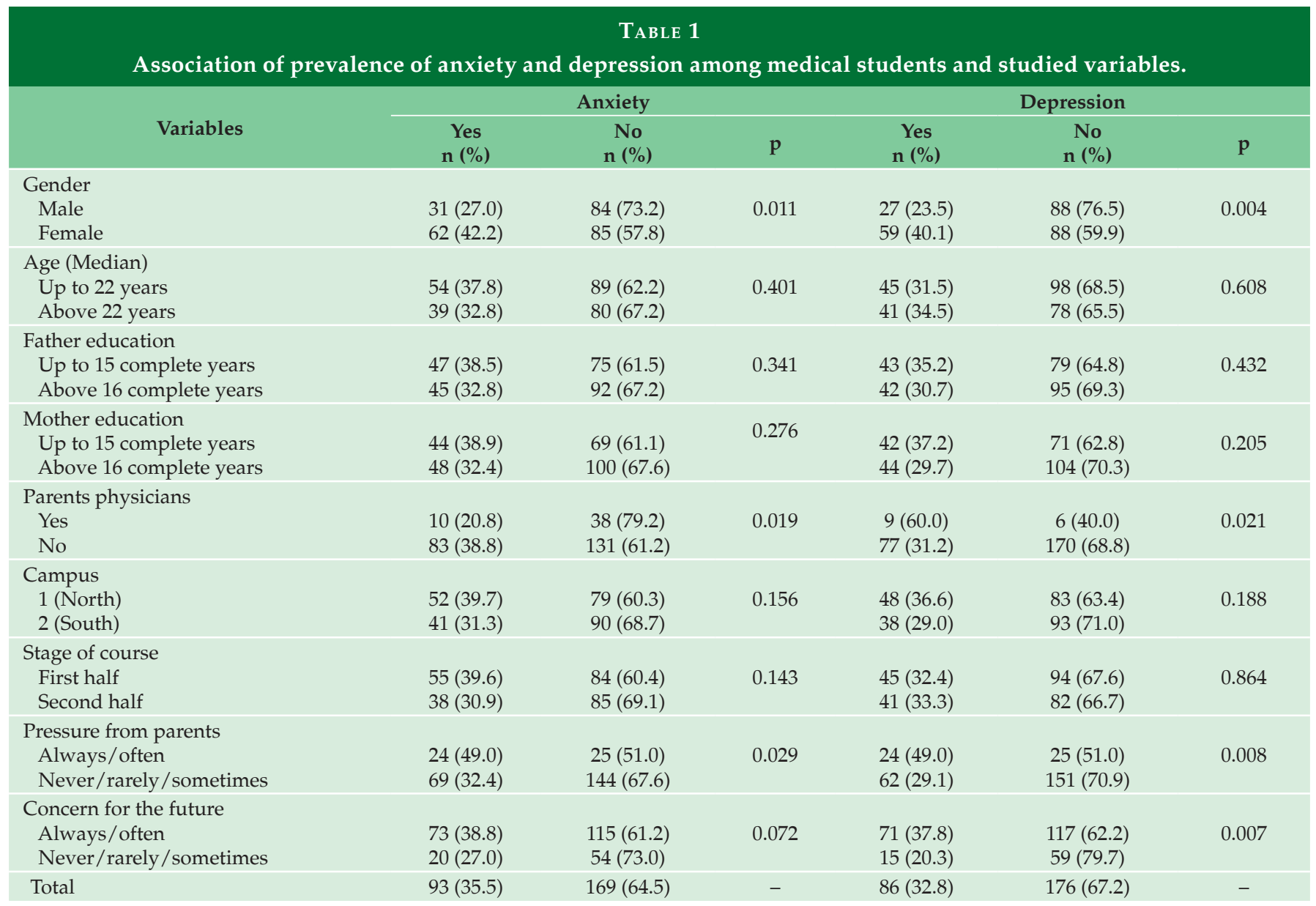

a medical occupation. In total, $95.8 \%$ reported feeling pressure from parents, and $68.7 \%$ expressed frequent concern for their professional future.

The prevalence of anxiety was 35.5\% (95\% CI: 29.7, 41.3) with the following distribution: $24.8 \%$ mild to moderate, $8.8 \%$ moderate and $1.9 \%$ severe, having a clinically significant anxiety rate of $8.5 \%$. The observed prevalence of depression was $32.8 \%$ (95\% CI: $27.2,38.4$ ), with the following distribution: $28.2 \%$ mild to moderate, $4.2 \%$ moderate to severe, and $0.4 \%$ severe.

Examination of the association between sociodemographic variables and prevalence of anxiety and depression showed strong association with female gender $(p=0.011$ and $p$ $=0.004$, respectively). There were no statistically significant associations with age, parental education and semester of medical school or campus where they studied. High pressure from parents was associated with anxiety $(p=0.029)$ and depression $(p=0.008)$. Students' concern for the future was also associated with depression ( $\mathrm{p}=0.007)$ (Table 1$)$.

The results of the multivariate analysis for anxiety (Table 2) showed that women had a $14 \%$ higher prevalence [OR =
$1.14(95 \%$ CI: $1.02,1.27)](\mathrm{p}=0.025)$ than men. Students whose parents were not physicians showed a $23 \%$ higher prevalence $[\mathrm{OR}=1.23$ (95\% CI: 1.67, 1.43)] ( $\mathrm{p}=0.006)$ compared to students whose parents were physicians. Similarly, those who were always or often pushed by their parents had a $22 \%$ higher prevalence [OR $=1.22(95 \% \mathrm{CI}: 1.06,1.42)](\mathrm{p}=0.006)$ compared to those who did not feel parental pressure. South campus students had a 13\% higher prevalence of anxiety [OR $=1.13(95 \% \mathrm{CI}: 1.01,1.26)](\mathrm{p}=0.044)$ than those attending classes on the North campus.

The results of multiple regression analysis for depression (Table 3) showed that women had a 16\% higher prevalence [OR $=1.16$ (95\% CI: 1.04, 1.30)] $(\mathrm{p}=0.006)$ than men. Students whose parents were physicians had a $29 \%$ higher prevalence [OR $=1.29$ (95\% CI: 1.02, 1.63) $](\mathrm{p}=0.034)$ compared to students whose parents were not physicians. Those who were always or often pushed by their parents had a 19\% higher prevalence $[\mathrm{OR}=1.19(95 \% \mathrm{CI}: 1.03,1.37)](\mathrm{p}=0.016)$ compared to those who did not feel parental pressure $(p=.016)$. Students who showed concern for the future had a $15 \%$ higher preva- 


\begin{tabular}{|c|c|c|c|c|}
\hline \multicolumn{5}{|c|}{$\begin{array}{l}\text { TABLE } 2 \\
\text { al model for anxiety among medical students. }\end{array}$} \\
\hline Variables & $\mathrm{PR}_{\mathrm{c}}(\mathrm{CI} 95 \%)$ & $\mathrm{p}$ & $\mathrm{PR}_{\mathrm{a}}(\mathrm{CI} 95 \%)$ & $\mathbf{P}$ \\
\hline $\begin{array}{l}\text { Gender } \\
\text { Male } \\
\text { Female }\end{array}$ & $\begin{array}{l}1.00 \\
1.16(1.04-1.31)\end{array}$ & 0.010 & $\begin{array}{l}1.00 \\
1.14(1.02-1.27)\end{array}$ & 0.025 \\
\hline $\begin{array}{l}\text { Parents physicians } \\
\text { Yes } \\
\text { No }\end{array}$ & $\begin{array}{l}1.00 \\
1.20(1.03-1.39)\end{array}$ & 0.018 & $\begin{array}{l}1.00 \\
1.23(1.67-1.43)\end{array}$ & 0.006 \\
\hline $\begin{array}{l}\text { Pressure from parents } \\
\text { Never/rarely/sometimes } \\
\text { Always/often }\end{array}$ & $\begin{array}{l}1.00 \\
1.18(1.02-1.37)\end{array}$ & 0.027 & $\begin{array}{l}1.00 \\
1.22(1.06-1.42)\end{array}$ & 0.006 \\
\hline $\begin{array}{l}\text { Concern for the future } \\
\text { Never/rarely/sometimes } \\
\text { Always/often }\end{array}$ & $\begin{array}{l}1.00 \\
1.12(0.99-1.28)\end{array}$ & 0.071 & $\#$ & \# \\
\hline $\begin{array}{l}\text { Campus } \\
1 \text { (North) } \\
2 \text { (South) }\end{array}$ & $\begin{array}{l}1.00 \\
1.09(0.97-1.22)\end{array}$ & 0.154 & $\begin{array}{l}1.00 \\
1.13(1.01-1.26)\end{array}$ & 0.044 \\
\hline $\begin{array}{l}\text { Stage of course } \\
\text { First half } \\
\text { Second half }\end{array}$ & $\begin{array}{l}1.00 \\
1.36(1.25-1.48)\end{array}$ & 0.143 & $\#$ & $\#$ \\
\hline
\end{tabular}

$P R_{b}=$ Crude prevalence ratio

$P R_{a}=$ Adjusted prevalence ratio.

$C I=$ Confidence interval.

\# = Removed from the model due loss of significance.

lence $[\mathrm{OR}=1.15(95 \% \mathrm{CI}: 1.03,1.31)](\mathrm{p}=0.017)$ than those who showed no concern for the future.

\begin{tabular}{|c|c|c|c|c|}
\hline $\begin{array}{r}\text { Results of mult } \\
\text { depressio }\end{array}$ & $\begin{array}{r}\text { TABLE } 3 \\
\text { Variate analy } \\
\text { among med }\end{array}$ & $\begin{array}{l}\text { is. Fi } \\
\text { cal st }\end{array}$ & $\begin{array}{l}\text { nal model fo } \\
\text { udents. }\end{array}$ & \\
\hline Variáveis & $\mathrm{PR}_{\mathrm{c}}(\mathrm{CI} 95 \%)$ & $\mathrm{p}$ & $\mathrm{PR}_{\mathrm{a}}(\mathrm{CI} 95 \%)$ & p \\
\hline $\begin{array}{l}\text { Gender } \\
\text { Male } \\
\text { Female }\end{array}$ & $\begin{array}{l}1.00 \\
1.18(1.05-1.32)\end{array}$ & 0.004 & $\begin{array}{l}1.00 \\
1.16(1.04-1.30)\end{array}$ & 0.006 \\
\hline $\begin{array}{l}\text { Parents physicians } \\
\text { Yes } \\
\text { No }\end{array}$ & $\begin{array}{l}1.00 \\
1.33(1.05-1.70)\end{array}$ & 0.020 & $\begin{array}{l}1.00 \\
1.29(1.02-1.63)\end{array}$ & 0.034 \\
\hline $\begin{array}{l}\text { Pressure from parents } \\
\text { Never/rarely/sometimes } \\
\text { Always/often }\end{array}$ & $\begin{array}{l}1.00 \\
1.22(1.06-1.41)\end{array}$ & 0.007 & $\begin{array}{l}1.00 \\
1.19(1.03-1.37)\end{array}$ & 0.016 \\
\hline $\begin{array}{l}\text { Concern for the future } \\
\text { Never/rarely/sometimes } \\
\text { Always/often }\end{array}$ & $\begin{array}{l}1.00 \\
1.19(1.05-1.35)\end{array}$ & 0.006 & $\begin{array}{l}1.00 \\
1.15(1.03-1.31)\end{array}$ & 0.017 \\
\hline $\begin{array}{l}\text { Campus } \\
1 \text { (Norte) } \\
2 \text { (Sul) }\end{array}$ & $\begin{array}{l}1.00 \\
1.08(0.96-1.21)\end{array}$ & 0.187 & $\#$ & \# \\
\hline
\end{tabular}

\section{DISCUSSION}

The aim of this study was to estimate the prevalence of anxiety and depression symptoms, and to analyze factors associated with these morbidities among medical students at a university in southern Brazil. Fort that purpose, widely used psychometric inventories ${ }^{7-8}$ were administered under the supervision of a trained psychologist.

Depression is notably more common among medical students than in the general population ${ }^{9}$. It is possible that medical students face more difficult situations of emotional imbalance, such as death within a family or termination of relationships, compared to the general population ${ }^{10}$. In southern Brazil, the estimated prevalence of depression in the general population of the same age group of that in this study is $12.6 \%{ }^{11}$. The present study showed a prevalence of $32.8 \%$, which is similar to that found in other studies that have used the BDI for the analysis of depression among medical students $^{3,12-15}$. The observed prevalence rate was higher than that found in two studies that, while using the same cut-off points, reported prevalence rates of depression of $23.1 \%{ }^{12}$ and $26.8 \%{ }^{13}$ among medical students. Similar prevalence rates were observed in a research conducted on 481 medical students in Sao Paulo (Brazil), which showed a prevalence of $38.2 \%{ }^{14}$. Depression scores were $28.6 \%$ for Arab students ${ }^{3}, 36.2 \%$ for Mexicans $^{15}$, and $39.8 \%$ for Persians ${ }^{16}$, using the same methodology.

Anxiety is another psychiatric morbidity which characteristically occurs more frequently among medical students than in the general population ${ }^{5}$. Factors such as pressure to learn, excessive study load, amount of new information and long work hours during residency, along with anxious personality traits, 
explain this characteristic association ${ }^{4,17}$. The prevalence of anxiety found in this study (35.5\%) stood considerably above the prevalence rate found in the literature ${ }^{3,18}$. Studies using similar methodology found prevalence rates of $28.7 \%$ in Arab medical students ${ }^{3}$ and between $24.1 \%$ and $25.1 \%$ in Indian students ${ }^{18}$.

Stressors that might be contributing to the high rates of depressive and anxiety symptoms included high pressure from parents, concern for the future, and gender, females being more prone than males to suffer from depression and anxiety disorders. Of these variables, only concern for the future was not linked to both anxiety and depression. Being associated with both morbidities may be due to the high correlation between them. High level of anxiety during adolescence has been viewed as a predictor of depression in adulthood ${ }^{19}$. Ahmed et al. ${ }^{3}$ detected significant correlation between anxiety and depression in medical students, which suggests a possible relationship of cause and effect in this population.

There is a consensus in the psychiatric literature that women tend to have more depressive and anxiety symptoms than men ${ }^{1,13,15-22}$. The present study corroborates this finding, since it showed that women had $14 \%$ higher prevalence of anxiety and $16 \%$ higher prevalence of depression compared to men. In studies with similar methodology ${ }^{1,13}$ women had higher scores of depressive symptoms than men. Blanch et al. ${ }^{22}$ observed the behavior of 141 American students in their third year of medical school during an important practical test and found that women demonstrated lower self-confidence and greater frequency of anxiety behavior than men. Several reasons could explain the higher prevalence rates of depression and anxiety in women compared to men, including greater social freedom for expression of feelings, greater exposure to situations of risk for depression, and physiological and hormonal factors ${ }^{21,23}$.

The family environment is seen as an important protective factor against the development of depressive disorders ${ }^{1,12,14,24-25}$. A study conducted on medical students in Colombia ${ }^{24}$ observed an increased risk of depression as the quality of family relationships decreased. In fact, the quality of parental bonding has demonstrated to be able to reduce the deleterious effects of stressors among medical students, leading to a functional adaptation $^{1}$. It is noteworthy that in this study the vast majority of students $(95.8 \%)$ reported that they often felt their parent's pressure upon them, which may be due to the high cost of medical school, leading parents to put pressure on their children to excel academically. At first, one might think that this would be beneficial for student achievement, but the findings in this study revealed that high parental pressure were associated with $22 \%$ higher prevalence of anxiety and $19 \%$ higher prevalence of depression in medical students compa- red to their counterparts. Sreeramareddy et al. ${ }^{26}$ investigated various sources of psychological stress in 407 medical students in Nepal, and found that high parental expectation was among the top stressors, along with the lack of time and the large number of tests and examinations. The continued search for parental approval can be a strong stressor leading to anxiety and depression. Having physician parents was a protective factor for anxiety but not for depression in medical students. Children of physician parents may have lower expectations of medical school than their counterparts ${ }^{26}$ and are more likely to develop social and affective coping skills ${ }^{27}$, which could explain the lower prevalence of anxiety. It is possible, however, that having physician parents could generate greater pressure for academic achievement and even greater concern for the future, which are two variables significantly associated with depression as demonstrated in this study.

Similar findings on concern for the future found in this study were observed in other studies in the sense that the heavy demands of the medical curriculum are important stressors both for anxiety and for depression $3,25,28$. Concern for academic achievement, along with personal and financial issues are potentially aggravating stressors affecting medical students ${ }^{14}$. Academic requirements for medical students are higher than those for other students, and include preparation for tests, job interviews, and medical residency exam, which is very stressing ${ }^{29}$.

Some authors believe that there are different stressors over a college program, depending on the level or semester at

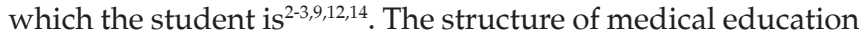
programs varies from one country to another ${ }^{20}$. There are many variations in the total number of years and many programs have early clinical practice, which impairs a clear division between clinical and pre-clinical stages ${ }^{14}$. The transition from the pre-clinical to clinical training has been identified as a crucial stage in relation to psychological stressors in medical school ${ }^{9}$. During that period, medical students undergo psychological transformations, are still immature and feel insecure about their responsibilities as future physicians ${ }^{3}$. However, similarly to what had occurred in the two mentioned studies, ${ }^{2,12}$ there was no statistical significance between the medical school semester and psychiatric disorders in this study.

\section{CONCLUSIONS}

The prevalence of depressive and anxiety symptoms found among medical students in this study was higher than the average found in the general population. There is indication that the psychosomatic injuries provided by depressive and anxiety morbidity inflicted to medical students are resulting from constant exhaustion and various stressors inherent to 
medical school, as previously explained. Prevalence of anxiety was higher in women than in men, and among those whose parents were not physicians and put much pressure on student achievement. Prevalence of depression was higher in women than in men, and among those who felt more parental pressure, with the difference that there were higher prevalence rates among those who had physician parents and were more concerned over the future than their counterparts.

\section{ACKNOWLEDGEMENTS}

The authors would like to thank the grant received from the Santa Catarina University Merit Program. Fapesc/Chamada Pública $n^{-0}$ 011/2009 - Prêmio Mérito Universitário. Grant: FCTP: $4018 / 095$.

\section{REFERENCES}

1. Rezende C, Abrão C, Coelho E, Passos L. Prevalence of depressive symptoms among medicine students of the University Federal of Uberlândia. Rev Bras Educ Med. 2008; 32(3):315-23.

2. Cavestro JDM, Rocha FL. Depression prevalence among university students. J Bras Psiq. 2006; 55(4):264-7.

3. Ahmed I, Banu H, Al-Fageer R, Al-Suwaidi R. Cognitive emotions: depression and anxiety in medical students and staff. J Crit Care. 2009; 24(3):e1-7.

4. Benevides-Pereira A, Gonçalves M. Emotional disorders during medical training: a longitudinal study. Rev Bras Educ Med. 2009; 33(1):10-23.

5. Dyrbye LN, Thomas MR, Shanafelt TD. Systematic review of depression, anxiety, and other indicators of psychological distress among U.S. and Canadian medical students. Acad Med. 2006; 81(4):354-73.

6. Dyrbye LN, Thomas MR, Shanafelt TD. Medical student distress: causes, consequences, and proposed solutions. Mayo Clin Proc. 2005; 80(12):1613-22.

7. Beck AT, Epstein N, Brown G, Steer RA. An inventory for measuring clinical anxiety: Psychometric properties. J Clin Cons Psychol. 1998; 56(6):893-7.

8. Beck AT, Ward CH, Mendelson M, Mock J. An inventory for measuring depression. Arch Gen Psychiatry. 1961; 4:461-571.

9. Dahlin ME, Runeson B. Burnout and psychiatric morbidity among medical students entering clinical training: a three year prospective questionnaire and interview-based study. BMC Med Educ. 2007; 7:6.

10. Gentile JG, Roman B. Medical student mental health services: psychiatrists treating medical students. Psychiatry. 2009; 6(5):38-45.
11. Lopez MRA, Ribeiro JP, Ores LC, Jansen K, Souza LDM, Pinheiro RT, et al. Depression and quality of life in young adults aged 18 to 24 years in southern Brazil. Rev Psiq Rio Gd Sul. 2011; 33(2):103-8.

12. Macedo PNAG, Nardotto LL, Dieckmann LHJ, Ferreira YD, Macedo BAG, Santos MAP, et al. Factors associated with depressive symptoms in a sample of Brazilian medical students. Rev Bras Educ Med. 2009; 33(4):595-604.

13. Amaral GFD, Gomide LMDP, Batista MDP, Píccolo PP; Teles TBG; Oliveira PM, et al. Depressive symptoms in medical students of Universidade Federal de Goiás: a prevalence study. Rev Psiq Rio Gd Sul. 2008; 30(2):124-30.

14. Baldassin S, Alves TCDTF, Andrade AG, Nogueira Martins LA. The characteristics of depressive symptoms in medical students during medical education and training: a cross-sectional study. BMC Med Educ. 2008; 8:60.

15. Melo-Carillo A, Oudenhove LV, Avila AL. Depressive symptoms among Mexican medical students: High prevalence and the effect of a group psychoeducation intervention. J Aff Dis. 2012; 136:1098-103.

16. Simin H, Zahra G. A survey Beck test in university students \& its relationship between some related risk factors. Procedia Soc Behav Sci. 2011; 28:558-62.

17. Yeh YC, Yen CF, Lai CS, Huang CH, Liu KM, Huang IT. Correlations between academic achievement and anxiety and depression in medical students experiencing integrated curriculum reform. Kaohsiung J Med Sci. 2007; 23(8):379-86.

18. Velayudhan A, Gayatridevi S, Bhattacharjee RR. Efficacy of behavioral intervention in reducing anxiety and depression among medical students. Ind Psychiatry J. 2010; 19(1):41-6.

19. Chaplin TM, Gillham JE, Seligman MEP. Gender, anxiety, and depressive symptoms: a longitudinal study of early adolescents. J Early Adolesc. 2009; 29(2):307-27.

20. Alexandrino-Silva C, Pereira MLG, Bustamante C. Ferraz AC, Baldassin S, Andrade AG, et al. Suicidal ideation among students enrolled in healthcare training programs: a cross-sectional study. Rev Bras Psiq. 2009: 31(4):338-44.

21. Zender R, Olshansky E. Women's mental health: depression and anxiety. Nurs Clin North Am. 2009; 44(3):355-64.

22. Blanch DC, Hall JA, Roter DL, Frankel RM. Medical student gender and issues of confidence. Pat Educ Counsel. 2008; 72:374-81.

23. Andrade LHSG; Viana MC; Silveira CM. Epidemiology of women's psychiatric disorders. Rev Psiq Clin. 2006; 33(2):43-54. 
24. Gaviria S, Rodríguez MA, Álvarez T. The quality of family relationships and depression in medical students in Medellin, Colombia, 2000. Rev Chil Neuro-Psiquiat. 2002; 40(1):41-6.

25. Mustafa MB, Nasir R, Yusooff F. Parental support, personality, self-efficacy and depression among medical students. Procedia Soc Behav Sci. 2010; 7(C):419-24.

26. Sreeramareddy CT, Shankar PR, Binu VS, Mukhopadhyay C, Ray B, Menezes RG. Psychological morbidity, sources of stress and coping strategies among undergraduate medical students of Nepal. BMC Med Educ. 2007; 7:26.

27. Rees $C$, Sheard C. The relationship between medical students' attitudes towards communication skills learning and their demographic and education-related characteristics. Med Educ. 2002; 36:1017-27.

28. Yusoff MS, Abdul Rahim AF, Baba AA, Ismail SB, Mat Pa MN, Esa AR. Prevalence and associated factors of stress, anxiety and depression among prospective medical students. Asian J Psychiatr. 2013; 6(2):128-33.

29. Enns MW, Cox BJ, Sareen J, Freeman P. Adaptive and maladaptive perfectionism in medical students: a longitudinal investigation. Med Educ. 2001; 35(11):1034-42.

\section{CONTRIBUTION OF AUTHORS}

Tabalipa FO, Souza and MF Traebert J participated in the study conception and its design. Tabalipa FO, Souza and MF Pfützenreuter G collected data. Tabalipa FO, Souza MF, Traebert E, Lima VC and J Traebert participated in the data analysis. Tabalipa FO, Souza MF, Lima VC, Traebert E and J Traebert participated in the drafting of the manuscript in its different versions. All authors approved the final version.

\section{CONFLICT OF INTERESTS}

None of the authors have any conflict of interest to disclose.

\section{CORRESPONDENCE}

Jefferson Traebert

Universidade do Sul de Santa Catarina

Campus Grande Florianópolis - Unidade Pedra Branca Avenida Pedra Branca, 25 - Cidade Universitária - Pedra

Branca - Palhoça

CEP 88137-270 - SC

E-mail: jefferson.traebert@gmail.com 